\title{
Meaningful Learning in Mathematics: A Research Synthesis of Teaching Approaches
}

\author{
Rauno Koskinen ${ }^{1 *} \mathbb{D}$, Harri Pitkäniemi ${ }^{2}$ (i)
}

${ }^{1}$ Department of Education, University of Helsinki, FINLAND

${ }^{2}$ School of Applied Education and Teacher Education, University of Eastern Finland, FINLAND

*Corresponding Author: rauno.koskinen@helsinki.fi

Citation: Koskinen, R., \& Pitkäniemi, H. (2022). Meaningful Learning in Mathematics: A Research Synthesis of Teaching Approaches. International Electronic Journal of Mathematics Education, 17(2), em0679. https://doi.org/10.29333/iejme/11715

\begin{tabular}{|c|c|}
\hline ARTICLE INFO & ABSTRACT \\
\hline Received: 28 Sep. 2021 & The premise on which our synthesis is based is the fragmentation of research focused on teaching and learning in \\
\hline Accepted: 1 Feb. 2022 & $\begin{array}{l}\text { mathematics. Our intention is to build an aggregate synthesis from these sources in the context of school } \\
\text { education and meaningful learning. Our research targets the links between the different approaches used in } \\
\text { teaching, interaction during the teaching-learning process and learning outcomes. Methodologically, our dataset } \\
\text { consists of qualitative, quantitative, and mixed-methods studies and meta-analyses. An EBSCO search produced } \\
69 \text { analysis-eligible publications from } 2007-2019 \text {. According to our findings, the use of contextual, concrete and } \\
\text { social approaches promotes meaningful learning in mathematics, although with certain refinements. The } \\
\text { analyses revealed that high-quality learning in mathematics requires guidance during student activities and } \\
\text { evaluation with immediate feedback during the teaching-learning process. It also requires the skill among } \\
\text { teachers to choose suitable contexts and learning tools, and to focus the students' communication on what is } \\
\text { relevant. Additional significant factors in a meaningful learning process include an affectively favourable } \\
\text { classroom atmosphere and teachers who treat their students as individuals. }\end{array}$ \\
\hline
\end{tabular}

Keywords: mathematics, teaching, learning, synthesis, holistic approach

\section{INTRODUCTION}

The National Council of Teachers of Mathematics (2014) has set meaningful learning as a key goal of mathematics teaching. "An excellent mathematics program requires effective teaching that engages students in meaningful learning through individual and collaborative experiences that promote their ability to make sense of mathematical ideas and reason mathematically" (p. 5). Understanding appears to be a key factor in different interpretations of the concept of meaningful learning. For example, Hiebert and Wearne (1992) define learning with understanding as the construction of connections between mathematical ideas and their various representations. Here, student motivation and commitment to working long term for understanding become also key factors. Therefore, appropriate teaching approaches to support meaningful learning have been under development for several decades. The National Council of Teachers of Mathematics (2014) recommends the use in teaching of real-world contexts, concrete aids and collaborative working practices. The question arises as to how these different approaches should be applied in the school classroom to promote meaningful learning.

Although the amount of empirical research on teaching mathematics has increased and the target area has expanded, the field is quite fragmented and the process of finding answers is challenging. Thus, a need has arisen for syntheses of different types. Quite a lot of meta-analyses and systematic literature reviews are currently available, focusing on different teaching approaches. Examples include incorporating physical activities (e.g., Vetter et al., 2020), multiple representations in mathematics teaching (e.g., Ge, 2012), problem-solving strategies (e.g., Kul \& Celik, 2020), computer-aided teaching (e.g., Brey \& Tagney, 2018; Xie et al., 2020), video and computer games (e.g., Byun \& Joung, 2018; Hainey et al., 2016), teaching based on collaborative learning (e.g., Capar \& Tarim, 2015), mathematical discussion and interaction (e.g., Richland et al., 2016), and focusing on a specific context such as learning disabilities (e.g., Benavides-Varela et al., 2021; Dennis et al., 2016; Lein et al., 2020).

Some studies address this field in its entirety. Nilsen and Gustafsson (2016, based on data from TIMSS 2007, 2011 surveys), for example, consider environmental factors in teaching such as education policy, school climate and the socioeconomic background of students. However, the main focus of the research is on the dimensions: teacher quality, instructional quality and learning outcomes, and the relationships among them. The closest concept to our research here is the instructional quality as a single dimension of that wider entity, referring here to teaching practices (e.g., cognitive activation, a supportive climate, and classroom management) that are linked to cognitive and affective learning outcomes in students. For example, Nilsen and Gustafsson (2016) 
found a clear positive association between the quality of teaching and both student achievement motivation and learning outcomes. The meta-analysis of Tumkaya and Ulum (2016), in turn, addressed the suitability of teaching methods, strategies and techniques in mathematics instruction (at the elementary-school level): the results showed that student-centred teaching strategies and techniques contributed to learning outcomes in maths. Teaching methods based on realistic mathematics teaching, computer-aided learning and collaborative learning were among the most significant approaches used in teaching. Tümkaya and Ulum's (2016) meta-analysis is the closest to our own research. Our study connects to the field formed by Chazan et al.'s (2016) instructional triangle (teaching-student-subject), but differs from previous studies in that the intention is to synthesize these elements of mathematics teaching. Therefore, our aim is to outline the whole range of teaching approaches, teacher-student interactions and learning outcomes.

\section{RESEARCH METHODOLOGY}

Teaching techniques and tools vary (there have been a few individual syntheses and meta-analyses, as we mentioned and exemplified in the introduction). Naturally, there are qualitative differences in the use and application of any teaching technique or instrument, but the psychological processes targeted at learning are, at least to some extent, the same regardless of the method. Studies, and in particular syntheses, should also focus on how to generate student-development processes on a general level (e.g., learner self-efficacy, participation, concentration, focus on understanding, success in problem solving), and how they constitute wider structures. We believe and conclude that there is a wide range of alternative "pathways" to good and meaningful learning output in the real world of teaching. The methods, therefore, appear to be, and are, functionally different, and the quality "within" each method or approach also varies. It is now a matter of discovering the valuable traits and components that form interactively functioning entities.

Datasets used in research syntheses may be restricted to qualitative studies. Thunder and Berry (2016) consider how the results of qualitative research could be combined (qualitative meta-synthesis), using mathematics education as a framework of reference for methodological review and development. Nye et al. (2016), in turn, look at the corresponding methodology on a general level. They criticize the fact that, although individual studies offer detailed descriptions and insights, the absence of delineated connections restricts their use. Meta-synthesis brings together and then breaks down the findings of several studies. The aim is to produce new findings that are more substantive in combination than the results of individual studies (Finfgeld, 2003).

Leary and Walker (2018) also consider different ways (including meta-analysis and meta-synthesis) of synthesizing research results. They define the notion of "mixing" as follows:

"Historically known as metastudy or sometimes a systematic review, a mixed-methods meta-synthesis uses quantitative and qualitative methods to approach an increased understanding of a concept. Combining quantitative and qualitative studies requires a researcher to use a meta-analysis method and then a qualitative meta-synthesis method, with a final synthesis step of uniting the findings together" (p. 531).

In their review, Wolgemuth et al. (2017) also systematize various reviews and syntheses of studies based on them. What is interesting is how the model construction or the production of summary results proceeds in different synthesis studies. For example, meta-analysis and best-evidence synthesis limit studies from a methodological perspective (i.e., there must be a certain kind of research design). Hence, the objects of research in meta-analyses are quantitative studies from the same area (based on the same concepts). Meta-studies draw from earlier studies based on qualitative methodology (theory, methods, and research findings) rather than quantitative studies.

Previous research syntheses may be inherently flawed when the totality of a particular phenomenon is under consideration. Some of them extend the description of the phenomenon to the extent that they do not include studies that are, strictly speaking, only "overlapping". According to a review by Wolgemuth et al. (2017), this mainly concerns narrative reviews, meta-narratives and critical interpretive syntheses. On the other hand, there have been various attempts at the wholesale takeover of a phenomenon. Several syntheses limit studies to either qualitative or quantitative research, but of course, there are exceptions. Wolgemuth et al.'s (2017) critical construct synthesis comes close to following the methodological principles we use in building our own research synthesis, specifically in that both quantitative and qualitative studies are used in the construction of the model.

For us, the starting point in choosing research methodology is not a single research question, it is rather the construction of a holistic model of the whole phenomenon and the manifold interactive forces and interactions that exist in it. The dataset in our study consists of various examples of research that methodologically touch on the phenomenon. The unifying characteristic is the teaching and learning of mathematics with an emphasis on meaningful learning. As a premise in determining our research objective, therefore, we considered (i) fragmentation and the need for aggregation and (ii) the failure of traditional quantitative metaanalysis and meta-synthesis focusing on qualitative research to construct wide-ranging conceptual syntheses.

A key step in the process of implementing a research synthesis is the search for and selection of research articles to be analysed. The first task is to determine the criteria using keywords. Then, as the process unfolds it becomes clear that not all the studies included in the preliminary data can be included in the analysis. In our own research, we took articles from the EBSCO database, which we justify because, in addition to the rich reference information, it also includes direct links to the relevant articles. We used the following keywords in our EBSCO searches: 'math "', 'teach"' and 'learning outcomes'. We selected peerreviewed research papers that appeared between 2007 and 2019. That search yielded 445 references overall.

Other descriptors are formulated as key selection criteria at this later stage. We chose studies that focus on mathematics in school education. Contexts that target early-childhood education, special class teaching, vocational training, universities, and 
other institutions of adult education were therefore excluded from the analysis. When we read the articles we paid attention not only to the learning outcomes of the students, but also to their processes of understanding, motivation and the affective dimension. We included studies with a focus that extended to learning with understanding (or a similar synonymous concept), or that evaluated learning in broad terms, but we also included indicators of meaningful learning (or a similar concept). Sixty-nine studies met all the above criteria, and therefore eventually comprized the study data.

\section{RESULTS}

The studies we analysed were classified according to their main results and the information was tabulated by topic. This review of the findings is divided into approaches to mathematics teaching $(n=43)$ and teacher-student interaction $(n=26)$.

\section{Teaching Approaches in Mathematics}

The drive for meaningful learning in mathematics teaching is reflected through the construction of the learning environment, the choice of teaching approaches, and the guiding of the teaching-learning process to the student's commitment to working together and furthering learning outcomes. The search identified many studies dealing with approaches used in mathematics teaching, which we divide here into three sub-categories: contextual, concrete, and social.

Contextual approaches reflect a model of action in which instruction progresses towards pure mathematics as learning content through the reviewing of real-world phenomena. The real-world context refers to all physical, social and cultural factors. These approaches highlight two essential features that are relevant for meaningful learning: a real-world connection and a problem orientation. Studies focusing on real-world connections have shown that linking learning content to the student's real or everyday world is essential for meaningful learning (Bernacki \& Walkington, 2018; Christie et al., 2016; Modiba, 2011; Reid \& Carmichel, 2015; Slavin et al., 2009). They have further revealed that a real-world orientation in mathematics teaching contributes to the development in learners of conceptual understanding, mathematical thinking, and motivation.

A problematic situation, often connected with real-world phenomena, serves as a starting point in problem-based teaching. Studies have shown that problem-based approaches promote student interest in mathematics (Ni et al., 2011; Nizami \& Mahmudi, 2018). Moreover, it seems that problem-based work methods influence the development of problem-solving and application skills in mathematics, as well as mathematical thinking (Davis, 2014; Guo et al., 2014; Ni et al., 2018; Norqvist et al., 2019; Olteanu \& Holmqvist, 2012; Rittle-Johnson et al., 2012). Such methods also frequently coincide with the quest for conceptual comprehension, resulting in a further improvement in learning outcomes (Cai et al., 2011; Jorgensen \& Niesche, 2008; Ni \& Cai, 2011; Ni et al., 2011). However, there are challenges connected with problem-based thinking.

In the case of mathematical problems, for example, there is typically no immediate solution and the process becomes stuck, which may lead to student frustration (Di Leo et al., 2019). It has also been shown that analysing one's own solutions and errors may improve learning outcomes (Hughes et al., 2019; Kapur, 2014). Here, however, assessing their own mistakes frequently left students confused or agonized (Di Leo et al., 2019; Richey et al., 2019). Affective challenges such as these have to be addressed if problem-based teaching approaches are to be optimally successful, hence the need to develop metacognitive skills and selfregulation among students. Table 1 depicts contextual approaches.

Table 1. Contextual approaches

\begin{tabular}{|c|c|c|c|}
\hline Study & Focus & Methodology & Main findings \\
\hline $\begin{array}{l}\text { Bernacki and } \\
\text { Walkington (2018) }\end{array}$ & $\begin{array}{l}\text { Secondary school students } \\
(\mathrm{N}=150)\end{array}$ & Quantitative & $\begin{array}{l}\text { Linking learning content to students' personal interests outside of school } \\
\text { led to better learning outcomes \& increased interest in maths. }\end{array}$ \\
\hline Cai et al. (2011) & $\begin{array}{l}\text { Reform classes ( } \mathrm{N}=25), 22 \text { giving } \\
\text { standard instruction, a total of } \\
1,284 \text { students) }\end{array}$ & $\begin{array}{l}\text { Quantitative, } \\
\text { longitudinal } \\
\text { study }\end{array}$ & $\begin{array}{l}\text { The approach, based on conceptual understanding \& problem solving } \\
\text { (reform in the US), positively contributed to development of problem- } \\
\text { solving \& application skills in mathematics (without adversely affecting } \\
\text { basic mathematics skills). }\end{array}$ \\
\hline $\begin{array}{l}\text { Christie et al. } \\
\quad(2016)\end{array}$ & $\begin{array}{l}\text { About } 150 \text { students (aged 11-14) } \\
\qquad \& 10 \text { teachers }\end{array}$ & Mixed methods & $\begin{array}{l}\text { Outdoor journeys as an approach developed students' metacognitive \& } \\
\text { critical thinking. It gave them the opportunity to learn about people \& } \\
\text { places in which they lived. Students also appreciated being allowed to } \\
\text { direct their own learning through their experience. }\end{array}$ \\
\hline Davis (2014) & $\begin{array}{l}\text { Students in two age groups: } 12- \\
15 \text { years } \& 15-18 \text { years }\end{array}$ & Quantitative & $\begin{array}{l}\text { This approach to reasoning \& proving yielded better learning outcomes } \\
\text { than when substance of reasoning \& proving was incorporated into } \\
\text { subject. }\end{array}$ \\
\hline Di Leo et al. (2019) & $\begin{array}{l}\text { Students from the } 5^{\text {th }} \& 6^{\text {th }} \\
\text { grades (Study1: } N=138, \text { Study2: } \\
\qquad N=79)\end{array}$ & Quantitative & $\begin{array}{l}\text { Dealing with frustration \& embarrassment that occurred during problem- } \\
\text { solving proved important. Overcoming these affective experiences } \\
\text { resulted in more positive feelings \& better learning outcomes for students. }\end{array}$ \\
\hline Guo et al. (2014) & $\begin{array}{l}\text { Randomly selected groups of } \\
\text { students (7th grade, } \mathrm{N}=263 \text { ) }\end{array}$ & Quantitative & $\begin{array}{c}\text { Learning \& application of an equation solution are supported by } \\
\text { comparison of a number of examples, selected so that their specifics are } \\
\text { essential to learning of a particular student. }\end{array}$ \\
\hline $\begin{array}{l}\text { Hughes et al. } \\
\text { (2019) }\end{array}$ & $\begin{array}{l}\text { Students from the } 5^{\text {th }} \& 8^{\text {th }} \\
\text { grades }(\mathrm{N}=27)\end{array}$ & Quantitative & $\begin{array}{c}\text { Student self-regulation \& self-assessment of problem solutions led to } \\
\text { better learning outcomes. }\end{array}$ \\
\hline Kapur (2014) & Students, aged $14-15(\mathrm{~N}=75)$ & Quantitative & $\begin{array}{l}\text { Problem-based instruction in mathematics led to a better conceptual } \\
\text { understanding \& application of what was learned in new situations than } \\
\text { direct instruction. Furthermore, taking advantage of students' own } \\
\text { mistakes promoted learning. }\end{array}$ \\
\hline
\end{tabular}


Table 1 (Continued). Contextual approaches

\begin{tabular}{|c|c|c|c|}
\hline Study & Focus & Methodology & Main findings \\
\hline $\begin{array}{l}\text { Ni and Cai } \\
\quad(2011)\end{array}$ & $\begin{array}{l}\text { Curriculum, results of two studies } \\
\text { (synthesized) }\end{array}$ & Qualitative & $\begin{array}{l}\text { Approaches based on conceptual understanding \& problem-solving } \\
\text { (reforms in China \& USA) positively impacted teaching quality \& } \\
\text { practices in class \&, further on, learning outcomes in mathematics. }\end{array}$ \\
\hline Ni et al. (2011) & $\begin{array}{l}\text { Classes ( } \mathrm{N}=60) \text { from } 20 \text { schools } \\
\text { (reform in } 34 \text { \& non-reform in } 26)\end{array}$ & $\begin{array}{l}\text { Quantitative } \\
\text { (learning outcomes } \\
\text { were assessed three } \\
\text { times over a period } \\
\text { of more than } 18 \\
\text { months) }\end{array}$ & $\begin{array}{l}\text { The approach, based on conceptual understanding \& problem solving } \\
\text { (reform in China), positively influenced learning of computation, \& both } \\
\text { routine \& complex problem solving. Students also became interested in } \\
\text { learning mathematics. }\end{array}$ \\
\hline Ni et al. (2018) & $\begin{array}{l}\text { Students from the } 5^{\text {th }} \text { grade } \\
(\mathrm{N}=1,779) \text {, from } 30 \text { classrooms }\end{array}$ & Quantitative & $\begin{array}{c}\text { Demanding problem-solving tasks \& various representations of learning } \\
\text { content had a positive impact on learning outcomes, student interest, } \\
\text { participation, \& development of a view on mathematics. }\end{array}$ \\
\hline $\begin{array}{l}\text { Nizami and } \\
\text { Mahmudi (2018) }\end{array}$ & Students from year $7(\mathrm{~N}=30)$ & Quantitative & $\begin{array}{l}\text { The problem-solving-based approach increased students' interest in } \\
\text { maths (65\% of students admitted to low interest prior to teaching } \\
\text { experiment). }\end{array}$ \\
\hline $\begin{array}{l}\text { Norqvist et al. } \\
\qquad(2019)\end{array}$ & $\begin{array}{l}\text { Among others, high school } \\
\text { students }(\mathrm{N}=48)\end{array}$ & $\begin{array}{l}\text { Quantitative, } \\
\text { eye tracking }\end{array}$ & $\begin{array}{l}\text { Use of problem-solving tasks requiring high levels of creativity in } \\
\text { teaching led to better learning outcomes than working on tasks of } \\
\text { which solution model had been taught previously. }\end{array}$ \\
\hline $\begin{array}{l}\text { Olteanu and } \\
\text { Holmqvist } \\
(2012)\end{array}$ & $\begin{array}{l}\text { Two teachers \& } 45 \text { students } \\
\text { (upper secondary school) }\end{array}$ & Qualitative & $\begin{array}{c}\text { Teaching solution of a second-order equation through its general } \\
\text { formula resulted in a better understanding \& broader management of } \\
\text { solution than teaching through special cases. }\end{array}$ \\
\hline $\begin{array}{l}\text { Reid and } \\
\text { Carmichael } \\
\quad(2015)\end{array}$ & $\begin{array}{l}\text { Primary school students, aged } 11 \text { - } \\
\qquad 12 \text { years }\end{array}$ & $\begin{array}{l}\text { Qualitative, case } \\
\text { study }\end{array}$ & $\begin{array}{c}\text { The approach, based on learning statistical concepts \& methods in } \\
\text { authentic contexts, strengthened students' understanding of statistical } \\
\text { concepts. They also obtained tools to enhance their understanding of } \\
\text { socio-cultural relationships. }\end{array}$ \\
\hline $\begin{array}{l}\text { Richey et al. } \\
\text { (2019) }\end{array}$ & $\begin{array}{l}\text { Students with a mean age of } 11.75 \\
\text { ( } \mathrm{N}=787 / 598) \text {, in two problem- } \\
\text { solving groups (focused on } \\
\text { incorrect \& correct solutions) }\end{array}$ & Quantitative & $\begin{array}{l}\text { Analysis of errors in solutions when solving problems initially made } \\
\text { students frustrated \& confused. Despite these experiences, learning } \\
\text { outcomes improved. }\end{array}$ \\
\hline $\begin{array}{l}\text { Rittle-Johnson } \\
\text { et al. (2012) }\end{array}$ & $\begin{array}{l}\text { Students, } 8^{\text {th }} \text { Grade }(\mathrm{N}=198) \\
\text { r\&omly allocated to different } \\
\text { circumstances }\end{array}$ & Quantitative & $\begin{array}{l}\text { Beginners trying a problem-solving approach who immediately used \& } \\
\text { combined multiple procedurals were more creative problem solvers } \\
\text { than others. }\end{array}$ \\
\hline $\begin{array}{l}\text { Slavin et al. } \\
\qquad(2009)\end{array}$ & $\begin{array}{l}\text { Learning outcomes, programmes } \\
\text { \& teaching in middle school \& } \\
\text { high school (Studies } \mathrm{N}=100 \text {, of } \\
\text { which treatment included } \mathrm{N}=26 \text { ) }\end{array}$ & Meta-analysis & $\begin{array}{l}\text { The approach, based on linking mathematics to real world, resulted in } \\
\text { better learning outcomes than those based on textbooks or technology } \\
\text { alone. It also combined collaborative \& computer-aided working } \\
\text { practices. }\end{array}$ \\
\hline
\end{tabular}

Concrete approaches in teaching mathematics refer to methods requiring the use of illustrative and manipulative tools, broken down into action-based and physical materials, computer programs and learning games. It is essential for teachers using illustrative tools to make sure that students are able to combine a mathematical idea with its external representations: the most important function of the tool is to highlight the precise features that facilitate understanding of the mathematical concept or operation in question. Particular attention is thus paid to the quality of the concrete materials and guidance in their use (Berthold \& Renkl, 2009; Carbonneau et al., 2013; Vitale et al., 2014). It has been found with the use of illustrative tools, for example, that a mathematical idea is better accessed by means of "bland manipulatives" (e.g., blocks) as opposed to "realistic manipulatives" (e.g., pieces of cake), so that the student's attention is more easily focused on what is essential (Carbonneau et al., 2013). In particular, research has shown that quality learning in younger students requires the use of manipulative and illustrative instruments (Ferrucci et al., 2009; Kainose Mhlolo \& Schafer, 2013).

Studies also attest to the importance of guidance. Students who receive optimal guidance achieve better learning outcomes than those who work independently (Berthold \& Renkl, 2009; Carbonneau et al., 2013). The use of sensorimotor experience to support the learning of abstract mathematics (embodied learning approaches or environments) has also been explored recently. Among other things, student bodily factors (e.g., communicating through hand and body movements) and movement (e.g., according to patterns or pathways marked in the classroom) have been utilized to facilitate the teaching of mathematics. These approaches have had a positive impact on students in terms of motivation, amenity and learning outcomes (Duijzer et al., 2019; Miller \& Lindt, 2018).

The development of computer technology has brought about a marked increase in the use of various aids (e.g., computers, tablets, smartphones and video game devices) in the teaching of mathematics and in related research, ranging from computer programs that support learning (Kong, 2008; Reed et al., 2010) to learning games that motivate students (Howard \& Crotty, 2017; Mavridis et al., 2017). All these things have reportedly had beneficial effects on learning. Computer tools and programs provide the opportunity to connect with various real-world phenomena and sources of information (Cai et al., 2019; Volk et al., 2017). Computer games have contributed significantly to the motivation of students, and to their feelings about and attitudes towards mathematics (Howard \& Crotty, 2017; Ke, 2008; Mavridis et al., 2017; Núñez Castellar et al., 2014). The use of quality games and good guidance also help to focus the attention of students on the learning content (Al-Washmi et al., 2015; Brezovszky et al., 2019; Rodriguez-Aflecht et al., 2018; Tokac et al., 2019). In this case, activities are supported by guiding questions, for example (Sun et al., 2014), or collaborative solutions (Ke, 2008). Table 2 shows concrete approaches. 
Table 2. Concrete approaches

\begin{tabular}{|c|c|c|c|}
\hline Study & Focus & Methodology & Main findings \\
\hline $\begin{array}{l}\text { Al-Washmi et al. } \\
\text { (2015). }\end{array}$ & Students from 7-10 years of age & $\begin{array}{l}\text { Qualitative, } \\
\text { experimental } \\
\text { design, period } 5 \\
\text { weeks }\end{array}$ & $\begin{array}{c}\text { Pedagogical computer games, when used well, positively contributed } \\
\text { to development of problem-solving skills \& learning outcomes as } \\
\text { students engaged in common activities. }\end{array}$ \\
\hline $\begin{array}{l}\text { Berthold and } \\
\text { Renkl (2009) }\end{array}$ & $\begin{array}{l}\text { Students from } 10^{\text {th }} \& 11^{\text {th }} \\
\text { grades, secondary school (girls } \\
\qquad \mathrm{N}=87 \text {, boys } \mathrm{N}=83 \text { ) }\end{array}$ & $\begin{array}{l}\text { Quantitative, } \\
\text { qualitative, } \\
\text { experimental } \\
\text { design }\end{array}$ & $\begin{array}{l}\text { Use of several representations of a mathematical idea in teaching } \\
\text { mathematics did not in itself improve conceptual comprehension. } \\
\text { However, by supporting student thinking (using colour codes \& auxiliary } \\
\text { questions linking essential factors), it enhanced learning. }\end{array}$ \\
\hline $\begin{array}{l}\text { Brezovszky et al. } \\
\text { (2019) }\end{array}$ & $\begin{array}{l}\text { Students from the } 4^{\text {th }}, 5^{\text {th }} \& 6^{\text {th }} \\
\text { grades }(\mathrm{N}=1,168)\end{array}$ & Quantitative & $\begin{array}{c}\text { Game-based approach (using number navigation game) resulted in } \\
\text { better learning outcomes than traditional mathematics teaching. }\end{array}$ \\
\hline Cai et al. (2019) & $\begin{array}{l}\text { Students from } 7^{\text {th }} \& 8^{\text {th }} \text { grades } \\
\qquad(\mathrm{N}=101)\end{array}$ & Quantitative & $\begin{array}{c}\text { Use of tablets \& real-world connectivity (augmented reality) helped } \\
\text { students to focus on higher-level concepts \& use more sophisticated } \\
\text { learning strategies. }\end{array}$ \\
\hline $\begin{array}{l}\text { Carbonneau et al. } \\
\qquad(2013)\end{array}$ & $\begin{array}{l}\text { Studies }(\mathrm{N}=55), 7,237 \text { students } \\
\text { of different ages }\end{array}$ & Meta-analysis & $\begin{array}{l}\text { Use of concrete manipulatives in mathematics per se or with a low level } \\
\text { of guidance did not significantly improve student achievement in } \\
\text { mathematics. However, in combination with other instructional factors } \\
\text { (such as choosing right type of manipulative \& appropriate level of } \\
\text { guiding), improvements were reported in conceptual understanding, } \\
\text { problem-solving \& transfer. }\end{array}$ \\
\hline
\end{tabular}

\begin{tabular}{|c|c|c|c|}
\hline & & & \\
\hline $\begin{array}{l}\text { Duijzer et al. } \\
\qquad(2019)\end{array}$ & $\begin{array}{l}\text { Studies ( } \mathrm{N}=44) \text {, conducted in } 62 \\
\text { different learning environments } \\
\text { (e.g., classrooms) among } \\
\text { students of different ages }\end{array}$ & $\begin{array}{l}\text { Systematic literary } \\
\text { review }\end{array}$ & $\begin{array}{c}\text { Embodied learning approaches, based specifically on combining } \\
\text { students' bodily experience with abstract mathematics, achieved better } \\
\text { learning outcomes than traditional teaching. }\end{array}$ \\
\hline $\begin{array}{l}\text { Ferrucci et al. } \\
\qquad(2009)\end{array}$ & $\begin{array}{l}\text { Traditional class, } 8^{\text {th }} \text { grade } \\
\text { students }\end{array}$ & $\begin{array}{l}\text { Quantitative, } \\
\text { qualitative, } \\
\text { multi-phase study }\end{array}$ & $\begin{array}{l}\text { Functional "bead-string" approach (hands-on activity), based on group } \\
\text { working \& real-world connection, had a positive impact on learning } \\
\text { outcomes. }\end{array}$ \\
\hline $\begin{array}{l}\text { Howard and } \\
\text { Crotty }(2017)\end{array}$ & $\begin{array}{l}\text { High-achieving mathematics } \\
\text { students in primary school } \\
\qquad(\mathrm{N}=30)\end{array}$ & Qualitative & $\begin{array}{l}\text { Interactive video learning game program had a positive impact on } \\
\text { students' motivation \& learning outcomes in mathematics. }\end{array}$ \\
\hline $\begin{array}{l}\text { Kainose Mhlolo } \\
\text { and Schafer (2013) }\end{array}$ & Students in $11^{\text {th }}$ grade $(\mathrm{N}=235)$ & Quantitative & $\begin{array}{l}\text { Students needed physical aids to understand idea of reflective } \\
\text { symmetry. }\end{array}$ \\
\hline Ke (2008) & Students from $5^{\text {th }}$ grade $(\mathrm{N}=487)$ & $\begin{array}{l}\text { Quantitative, } \\
\text { qualitative. } \\
\text { Mixed methods, } \\
\text { quasi-experimental } \\
\text { research design }\end{array}$ & $\begin{array}{l}\text { Use of computer games as a learning tool clearly had a stronger impact } \\
\text { on learning motivation than an activity using only paper \& pen. } \\
\text { Combining a collaborative approach with games led to further } \\
\text { improvement in students' attitudes towards learning mathematics. }\end{array}$ \\
\hline Kong (2008) & Students from $4^{\text {th }}$ grade $(\mathrm{N}=36)$ & Quantitative & $\begin{array}{l}\text { Cognitive tool as a pedagogical aid in teaching fractional numbers } \\
\text { enabled students to develop their procedural knowledge of subject \& } \\
\text { increased collaboration among them. Students were also enthusiastic } \\
\text { about using medium. }\end{array}$ \\
\hline $\begin{array}{l}\text { Mavridis et al. } \\
\qquad(2017)\end{array}$ & $\begin{array}{l}\text { Students }(\mathrm{N}=79) \text { who were } \\
\text { randomly divided into a test \& a } \\
\text { control group. Four teachers }\end{array}$ & $\begin{array}{l}\text { Quantitative, } \\
\text { including } \\
\text { interviews }\end{array}$ & $\begin{array}{c}\text { Use of an online flexible educational game in teaching improved } \\
\text { student attitudes towards mathematics \& also led to better learning } \\
\text { outcomes. }\end{array}$ \\
\hline $\begin{array}{l}\text { Miller and Lindt } \\
\qquad(2018)\end{array}$ & $\begin{array}{l}\text { Students in } 2^{\text {nd }} \& 3^{\text {rd }} \text { grades } \\
\qquad(N=76)\end{array}$ & Mixed methods & $\begin{array}{l}\text { An approach that combined study of learning content \& interaction with } \\
\text { physical movement of students resulted in enhanced student interest \& } \\
\text { engagement, as well as better learning outcomes than traditional } \\
\text { teaching. }\end{array}$ \\
\hline $\begin{array}{l}\text { Núñez Castellar et } \\
\text { al. (2014) }\end{array}$ & Second-year students $(\mathrm{N}=88)$ & $\begin{array}{l}\text { Quantitative, } \\
\text { qualitative }\end{array}$ & $\begin{array}{l}\text { Pedagogical maths game had a positive effect on students' affective } \\
\text { (e.g., math-anxiety, pleasure) \& cognitive learning outcomes. }\end{array}$ \\
\hline Reed et al. (2010) & $\begin{array}{l}\text { Students from } 7^{\text {th }} \& 8^{\text {th }} \text { grades } \\
\qquad(N=565)\end{array}$ & Mixed methods & $\begin{array}{l}\text { Mathematical computer tools were found to strengthen student } \\
\text { learning. However, this also required support to improve students' } \\
\text { attitudes, studying behaviour, \& mathematical knowledge construction } \\
\text { in meaningful discourse. }\end{array}$ \\
\hline $\begin{array}{l}\text { Rodriguez-Aflecht } \\
\text { et al. (2018) }\end{array}$ & Students from year $5(\mathrm{~N}=212)$ & Quantitative & $\begin{array}{c}\text { Learning games can be used to promote student learning. However, } \\
\text { choice of game should be based not only on its motivational impact, } \\
\text { but also on its effectiveness in improving learning outcomes (e.g., } \\
\text { number navigation game). }\end{array}$ \\
\hline Tokac et al. (2019) & $\begin{array}{l}\text { Studies }(\mathrm{N}=24) \text {. Students from } \\
\text { preschool, grades } 1-6 \& 7-12\end{array}$ & Meta-analysis & $\begin{array}{l}\text { Approaches based on video games proved to be slightly more effective } \\
\text { (taking into account learning outcomes) than traditional teaching } \\
\text { strategies. }\end{array}$ \\
\hline Vitale et al. (2014) & $\begin{array}{l}80 \text { students in the } 2^{\text {nd }}, 3^{\text {rd }} \& 4^{\text {th }} \\
\text { grades }\end{array}$ & Quantitative & $\begin{array}{l}\text { In context of using concrete materials, difficulties in operation were } \\
\text { found to support mathematics learning. These difficulties focused } \\
\text { students' attention on connection between essential elements of } \\
\text { learning tool \& learning task. }\end{array}$ \\
\hline Volk et al. (2017) & $\begin{array}{l}\text { School classes ( } 3^{\text {rd }} \text { grade) } \mathrm{N}=12 \text {. } \\
\text { Students in test group }(\mathrm{N}=124) \text {, } \\
\text { \& in the control group }(\mathrm{N}=135)\end{array}$ & $\begin{array}{l}\text { Quantitative, } \\
\text { including } \\
\text { interviews }\end{array}$ & $\begin{array}{l}\text { Use of tablets as a learning tool in mathematics had a positive impact } \\
\text { on students' cognitive, affective, \& psychomotor learning outcomes. It } \\
\text { also facilitated connection to different sources \& levels of } \\
\text { representation (concrete, visual, \& abstract). }\end{array}$ \\
\hline
\end{tabular}


Table 3. Social approaches

\begin{tabular}{|c|c|c|c|}
\hline Study & Focus & Methodology & Main findings \\
\hline $\begin{array}{l}\text { Hofmann and } \\
\text { Ruthven (2018) }\end{array}$ & $\begin{array}{l}\text { Students, } 12 \text { teachers, } 14 \text { different } \\
\text { classes, } 21 \text { lessons }\end{array}$ & Qualitative & $\begin{array}{l}\text { Teaching during which communicative activities were built on students' } \\
\text { personal ideas led to more active participation in class discussion \& better } \\
\text { learning outcomes. }\end{array}$ \\
\hline $\begin{array}{l}\text { Muis et al. } \\
\quad(2016)\end{array}$ & Primary school students $(\mathrm{N}=78)$ & $\begin{array}{l}\text { Quantitative, } \\
\text { qualitative, } \\
\text { intervention }\end{array}$ & $\begin{array}{l}\text { A collaborative approach in which students taught each other developed } \\
\text { conceptual understanding, problem-solving skills, \& commitment to } \\
\text { metacognitive strategies. }\end{array}$ \\
\hline $\begin{array}{l}\text { Pampaka et al. } \\
\qquad(2012)\end{array}$ & $\begin{array}{l}\text { More than } 1,000 \text { students \& their } \\
\text { teachers }\end{array}$ & $\begin{array}{l}\text { Quantitative, } \\
\text { qualitative, } \\
\text { mixed methods }\end{array}$ & $\begin{array}{c}\text { Communicative approaches were found to promote learning of } \\
\text { mathematics. However, they did not appear to affect future goals related } \\
\text { to studying mathematics. }\end{array}$ \\
\hline $\begin{array}{l}\text { Smith and } \\
\text { Mancy (2018) }\end{array}$ & Students, aged 9-10 $(\mathrm{N}=12)$ & Qualitative & $\begin{array}{l}\text { An individual's cognitive thought processes merged with collaborative } \\
\text { processes in group work based on problem solving. This led to } \\
\text { development of metacognitive communication, which in turn led to better } \\
\text { learning outcomes. }\end{array}$ \\
\hline $\begin{array}{l}\text { Souvignier and } \\
\text { Kronenberger } \\
(2007)\end{array}$ & $\begin{array}{l}\text { Classrooms } 9,3^{\text {rd }} \text { grade students } \\
\qquad(\mathrm{N}=208)\end{array}$ & Quantitative & $\begin{array}{l}\text { A collaborative approach (expert \& home groups) in primary-school } \\
\text { context had a positive impact on learning outcomes in geometry. }\end{array}$ \\
\hline $\begin{array}{l}\text { Ziegler et al. } \\
\qquad(2018)\end{array}$ & Students from the $6^{\text {th }}$ grade $(N=153)$ & Quantitative & $\begin{array}{c}\text { Approach focused on conceptual comprehension \& verbalizing of } \\
\text { mathematics yielded better learning outcomes than approach focused on } \\
\text { problem solving. }\end{array}$ \\
\hline
\end{tabular}

Social approaches are based on the socio-constructivist view of learning. Studies specifically target collaborative learning methods, class discussion, group working, participation and communication (Hofmann \& Ruthven, 2018; Muis et al., 2016; Pampaka et al., 2012; Smith \& Mancy, 2018; Souvignier \& Kronenberger, 2007). In particular, the need for more collaborative learning practices and communication in maths lessons has been highlighted. Several studies report that collaborative working practices in mathematics promote student motivation, commitment to joint activity and learning outcomes (Muis et al., 2016; Smith \& Mancy, 2018; Souvignier \& Kronenberger, 2007). Table 3 summarizes social approaches.

Collaborative activities are often coupled with other teaching approaches, whereby the combined effect has been to improve learning outcomes (Ferrucci et al., 2009; Ke, 2008; Kong, 2008; Muis et al., 2016; Slavin et al., 2009; Smith \& Mancy, 2018; Souvignier \& Kronenberger, 2007). One key outcome of group working and collaborative activity is the increase of communication among students, which in the case of mathematics has been found significantly to improve learning outcomes (Hofmann \& Ruthven, 2018; Muis et al., 2016; Pampaka et al., 2012). Students need to develop their skills in mathematical communication, specifically regarding the formation of the language of mathematics, their conceptual understanding and their internalization of learning content (Ziegler et al., 2018).

In sum, teaching aimed at conceptual comprehension produces better learning outcomes and more in-depth skills than teaching weighted towards mechanical numeracy. According to the studies featured here, contextual, concrete and social approaches play a large role in the meaningful learning of mathematics. For example, activities such as linking pure mathematics to real-world phenomena and learning to understand it using concrete tools reflect the student's mental processes in a positive way. What matters here is that students are able to interpret something new through their real-world-connected conceptual framework and thereby to build up their understanding. Once again, motivation is influenced by the fact that students see where mathematics is really needed. In addition, better learning outcomes have been achieved through approaches based on social interaction than through working solely with textbooks and calculation exercises. Research has shown that increased communication and an emphasis on language in the teaching of mathematics may deepen student understanding and learning. What is most significant in these approaches is the enhanced activity and motivation of students as they participate in the everyday activities of the class. When well implemented (e.g., choice of tools and control of activities), the above approaches support understanding, motivation, and the development of positive attitudes towards mathematics among students.

\section{Teacher-Student Interaction}

The search yielded several studies focused on teacher-student interaction and communication that specifically highlight the importance of guiding student learning during the teaching-learning process. Information on interactions related to this process is compiled under the following themes: engaging students in the learning process (Table 4), interaction and guidance during the teaching-learning process (Table 5), and the emotional climate of the learning environment as a maintainer of the student's learning process (Table 6). 
Table 4. Engaging students in the learning process

\begin{tabular}{|c|c|c|c|}
\hline Study & Focus & Methodology & Main findings \\
\hline Amador (2016) & $\begin{array}{l}\text { Four teachers of } 4^{\text {th }} \text { graders } \& \text { their } \\
\text { students }\end{array}$ & $\begin{array}{l}\text { Qualitative, case } \\
\text { study }\end{array}$ & $\begin{array}{l}\text { Focusing of teacher's attention on students' mathematical thinking \& } \\
\text { conceptual understanding promoted learning \& led to better learning } \\
\text { outcomes. }\end{array}$ \\
\hline $\begin{array}{l}\text { Azigve et al. } \\
\qquad(2016)\end{array}$ & $\begin{array}{l}\text { Students from } 6^{\text {th }} \text { grade. } \\
\text { Classes/teachers }(\mathrm{N}=99) \& \text { their } \\
\text { students }(\mathrm{N}=4,386)\end{array}$ & Quantitative & $\begin{array}{l}\text { Certain teacher factors (orientation, structuring activities, questioning, } \\
\text { teaching structuring, application, time-use management, regulation, \& } \\
\text { evaluation of the learning environment) had a positive impact on } \\
\text { students' learning outcomes. }\end{array}$ \\
\hline Csapó (2007) & Students from $7^{\text {th }} \& 11^{\text {th }}$ grades & Quantitative & $\begin{array}{l}\text { A teaching strategy that favoured productive learning led to meaningful } \\
\text { conceptual learning more effectively than a reproductive strategy. In } \\
\text { addition, immediate orientational feedback supported student learning. }\end{array}$ \\
\hline $\begin{array}{l}\text { Gresalfi et al. } \\
\qquad(2009)\end{array}$ & Students from $6^{\text {th }}, 7^{\text {th }} \& 8^{\text {th }}$ grades & Qualitative & $\begin{array}{l}\text { Guiding students \& focusing their attention on essential had a positive } \\
\text { impact on their learning. Teaching that has clear goals supports } \\
\text { participation \& learning among students when they know what is } \\
\text { expected of them. }\end{array}$ \\
\hline Huy (2014) & Students from $12^{\text {th }}$ grade $(\mathrm{N}=262)$ & $\begin{array}{l}\text { Quantitative, } \\
\text { longitudinal } \\
\text { study }\end{array}$ & $\begin{array}{l}\text { Learning-goal orientation among students was found to promote study \& } \\
\text { led to better learning outcomes. }\end{array}$ \\
\hline $\begin{array}{l}\text { Marshall et al. } \\
\qquad(2009)\end{array}$ & $\begin{array}{l}\text { Students in } 3^{\text {rd }}(N=6,800) \& 6^{\text {th }} \\
\text { grades }(N=6,000)\end{array}$ & Quantitative & $\begin{array}{l}\text { Results showed that high-quality mathematical knowledge \& solid } \\
\text { pedagogical knowledge among teachers were prerequisites for success in } \\
\text { guiding students through a meaningful learning process. This continued to } \\
\text { predict higher student scores in mathematics. }\end{array}$ \\
\hline $\begin{array}{l}\text { Matos et al. } \\
(2017)\end{array}$ & $\begin{array}{l}\text { Secondary school students, data } 1 \\
\quad(N=1,505) \& \text { data } 2(N=551)\end{array}$ & Quantitative & $\begin{array}{c}\text { Adoption of a learning-goal orientation led to stronger commitment to } \\
\text { learning process \& better learning outcomes among students. }\end{array}$ \\
\hline Modiba (2011) & Teacher, $1^{\text {st }}$ grade students $(\mathrm{N}=35)$ & Qualitative & $\begin{array}{l}\text { Teaching focused on developing understanding \& a positive attitude } \\
\text { requires of teacher in-depth maths knowledge \& competence in guiding } \\
\text { students through their learning process. A lack of understanding among } \\
\text { students of reasons behind maths rules \& procedurals leads to poorer } \\
\text { learning outcomes. }\end{array}$ \\
\hline $\begin{array}{l}\text { Simões and } \\
\text { Alarcão (2014) }\end{array}$ & $\begin{array}{l}\text { Mentored }(N=157) \text { \& non-mentored } \\
(N=160) \text { students from grades } 5-8\end{array}$ & $\begin{array}{l}\text { Quantitative, } \\
\text { longitudinal } \\
\text { study }\end{array}$ & Mentoring as student support had a positive impact on learning outcomes. \\
\hline Singer (2009) & $\begin{array}{l}\text { Students from grades } 1-4,9 \\
\text { classrooms }(\mathrm{N}=232)\end{array}$ & $\begin{array}{l}\text { Qualitative, } \\
\text { experimental. } \\
\text { Mixed methods }\end{array}$ & $\begin{array}{l}\text { Mathematics teaching that activated students' mental operational } \\
\text { infrastructure proved to enhance learning, flexible mathematical thinking, } \\
\text { \& creative problem solving. }\end{array}$ \\
\hline
\end{tabular}

Table 5. Interaction and guidance during the teaching-learning process

\begin{tabular}{|c|c|c|c|}
\hline Study & Focus & Methodology & Main findings \\
\hline $\begin{array}{l}\text { Chadli et al. } \\
\qquad(2018)\end{array}$ & Students from $2^{\text {nd }}$ grade $(\mathrm{N}=52)$ & Quantitative & $\begin{array}{l}\text { Computer-aided guidance supported students in their problem solving, } \\
\text { helped them to overcome difficulties, \& developed their problem-solving } \\
\text { skills. }\end{array}$ \\
\hline $\begin{array}{l}\text { Fuchs et al. } \\
\qquad(2008 a)\end{array}$ & Students from $3^{\text {rd }}$ grade $(N=122)$ & $\begin{array}{l}\text { Quantitative, } \\
\text { qualitative }\end{array}$ & $\begin{array}{l}\text { Dynamic assessment targeting potential of students to learn mathematics } \\
\text { is more supportive of learning than assessment targeting their existing } \\
\text { ability to perform given task. }\end{array}$ \\
\hline $\begin{array}{l}\text { Fuchs et al. } \\
\qquad(2008 b)\end{array}$ & $\begin{array}{l}\text { Students in } 3^{\text {rd }} \text { grade with } \\
\text { shortcomings in maths learning }\end{array}$ & $\begin{array}{l}\text { Qualitative, } \\
\text { quantitative }\end{array}$ & $\begin{array}{c}\text { Study highlighted following seven principles that had a positive impact on } \\
\text { the learning of students with serious deficiencies: clarity of instruction, } \\
\text { minimizing learning challenges, a strong conceptual base for learning, } \\
\text { practice \& repetition, a review of activities, work motivation \& continuous } \\
\text { development assessment. }\end{array}$ \\
\hline $\begin{array}{l}\text { Fuchs et al. } \\
\qquad(2013)\end{array}$ & $\begin{array}{l}\text { At-risk students at different levels } \\
\text { of tutoring ( } N=195, N=190, N=206)\end{array}$ & Quantitative & $\begin{array}{l}\text { Tutored practice strengthened learning better than untutored practice. } \\
\text { Speeded tutored practice (including quick response \& feedback, use of } \\
\text { effective computation methods \& producing several correct solutions) } \\
\text { helped students in at-risk group to compensate for their poor reasoning } \\
\text { ability. }\end{array}$ \\
\hline $\begin{array}{l}\text { Kim et al. } \\
(2018)\end{array}$ & $\begin{array}{l}\text { Studies }(\mathrm{N}=21) \text {. Students of } \\
\text { different ages in contexts based on } \\
\text { problem-based learning. }\end{array}$ & Meta-analysis & $\begin{array}{l}\text { Computer-aided guidance supported the students in their problem solving } \\
\qquad \& \text { led to better cognitive learning outcomes. }\end{array}$ \\
\hline $\begin{array}{l}\text { O’Connor } \\
\text { al. }(2017)\end{array}$ & $\begin{array}{l}\text { Students from } 6^{\text {th }} \text { grade. In } \\
\text { comparison, } 2 \text { sixth classes } Q \\
(\mathrm{~N}=44)\end{array}$ & Quantitative & $\begin{array}{l}\text { No connection was found between learning outcomes \& degree to } \\
\text { which students participating in class discussion contributed } \\
\text { vocally during lessons. }\end{array}$ \\
\hline $\begin{array}{l}\text { Schwonke et } \\
\text { al. (2011) }\end{array}$ & Secondary school students $(N=125)$ & $\begin{array}{l}\text { Quantitative, } \\
\text { experimental }\end{array}$ & $\begin{array}{l}\text { Acquisition of procedural knowledge through problem solving alone (in } \\
\text { case of easier tasks) proved to be possible, whereas acquisition of } \\
\text { conceptual knowledge required more support. }\end{array}$ \\
\hline $\begin{array}{l}\text { Sun et al. } \\
(2014)\end{array}$ & Students aged $14-15(\mathrm{~N}=81)$ & Quantitative & $\begin{array}{l}\text { Guiding questions integrated into action positively influenced students in } \\
\text { their computer search for mathematical information: students read more } \\
\text { information \& were also more positive about action. }\end{array}$ \\
\hline
\end{tabular}


Table 5 (Continued). Interaction and guidance during the teaching-learning process

\begin{tabular}{|c|c|c|c|}
\hline Study & $\begin{array}{c}\text { Focus } \\
\end{array}$ & Methodology & Main findings \\
\hline $\begin{array}{l}\text { van der Kleij et } \\
\text { al. (2015) }\end{array}$ & $\begin{array}{l}\text { Students of different ages in a } \\
\text { computer-based learning } \\
\text { environment, studies }(\mathrm{N}=40)\end{array}$ & Meta-analysis & $\begin{array}{c}\text { Immediate explanatory feedback from teacher directed at student's } \\
\text { thinking \& learning process (not just correctness/incorrectness of answer) } \\
\text { positively affected learning outcomes. }\end{array}$ \\
\hline Vista (2013) & $\begin{array}{l}\text { Students from diverse linguistic } \\
\text { backgrounds }(N=5,886)\end{array}$ & Quantitative & $\begin{array}{l}\text { Proficiency in reading comprehension had a positive impact on students' } \\
\text { learning outcomes (via an indirect link through reasoning skill to learning } \\
\text { mathematics). No significant effect of language background was found. }\end{array}$ \\
\hline $\begin{array}{l}\text { Wakefield et } \\
\text { al. (2018) }\end{array}$ & Students, aged 8-10 ( $\mathrm{N}=50)$ & $\begin{array}{l}\text { Quantitative, eye } \\
\text { tracking }\end{array}$ & $\begin{array}{l}\text { Teaching that combined body movements (e.g., hands) with instructional } \\
\text { talk helped students to follow talk, concentrate, \& engage. This pattern of } \\
\text { activity resulted in better learning outcomes compared to instructional } \\
\text { talk that was not supported by body movements. }\end{array}$ \\
\hline $\begin{array}{l}\text { Wood and } \\
\text { Kalinec (2012) }\end{array}$ & Three cases, $4^{\text {th }}$ grade students & Qualitative & $\begin{array}{l}\text { Quality of mathematics talk played a greater role in learning outcomes } \\
\text { than amount of talk. Hence, engaging students in quality mathematical } \\
\text { communication proved to be important. }\end{array}$ \\
\hline
\end{tabular}

Table 6. The emotional climate of the learning environment as a maintainer of the learning process

\begin{tabular}{cccc}
\hline Study & Focus & Methodology & Main findings \\
\hline $\begin{array}{c}\text { Daschmann et } \\
\text { al. (2011) }\end{array}$ & $\begin{array}{c}\text { Students from grades 5-10 } \\
(\mathrm{N}=1,380)\end{array}$ & Quantitative & $\begin{array}{c}\text { Students were more comfortable with \& more involved in common } \\
\text { activities, \& felt that mathematics was relevant to themselves, if teacher } \\
\text { considered their individual differences. }\end{array}$ \\
\hline $\begin{array}{c}\text { Jorgensen and } \\
\text { Niesche (2008) }\end{array}$ & $\begin{array}{c}\text { Disadvantaged students along } \\
\text { social-class, race \& gender lines }\end{array}$ & $\begin{array}{c}\text { Systematic } \\
\text { literary review }\end{array}$ & $\begin{array}{c}\text { Learning among disadvantaged students was best supported in an } \\
\text { environment in which mathematics was learned in a variety of rich } \\
\text { contexts \& collaboratively, reflecting what mathematicians do. Teacher } \\
\text { acted as a counsellor \& inspirer, supporting individuals in their own } \\
\text { thinking \& expression. }\end{array}$ \\
\hline $\begin{array}{c}\text { Kiuru et al. } \\
\text { (2015) }\end{array}$ & $\begin{array}{c}\text { Students from different levels, from } \\
\text { early childhood education to 4h } \\
\text { grade (N=625) }\end{array}$ & Quantitative & $\begin{array}{c}\text { Teacher's warm \& supportive attitude towards students had a positive } \\
\text { impact on their attitudes towards their teacher \& each other. This also had } \\
\text { a positive association with learning outcomes. }\end{array}$ \\
\hline $\begin{array}{c}\text { Venkat and } \\
\text { Brown (2009) }\end{array}$ & Students from grades 7-9 & $\begin{array}{c}\text { A longitudinal, } \\
\text { comparative } \\
\text { case study }\end{array}$ & $\begin{array}{c}\text { A learning environment based on traditional classroom instruction led to } \\
\text { an increase in dissatisfaction \& teacher dependence. In turn, an } \\
\text { environment based on individual teaching led to an increase in student } \\
\text { enthusiasm \& independence. }\end{array}$ \\
\hline
\end{tabular}

Research has shown that better learning outcomes are achieved in mathematics teaching when the underlying aim of the activities is to promote conceptual understanding among the students (Amador 2016; Csapó, 2007; Ziegler et al., 2018). This highlights the importance of the teacher's mathematics and pedagogical knowledge as prerequisites for success in guiding students through the learning process (Marshall et al., 2009; Modiba, 2011). One of the main tasks of the teacher at the beginning of a joint activity is to discuss the goals with the students. Research results indicate that this contributes significantly to student participation and amenity (Azigve et al., 2016; Daschmann et al., 2011; Gresalfi et al., 2009). Another necessary task when approaching a new subject is to activate the students' previous knowledge to which the new learning content is to be attached. Study findings imply that this is a prerequisite for learning with understanding, as well as for the further development of mathematical thinking and creative problem solving (Fuchs et al., 2008b; Singer, 2009).

When the goal of teaching is to promote the understanding of mathematics, it is essential to generate initial motivation and to engage students in the learning process. Internal motivation ties them to long-term semantic working. The concept of a learning goal orientation has also been used in this context, referring to the student's attempt to learn and to understand the content presented in teaching. It has also been found that such an orientation promotes deep learning, high-quality conceptual understanding, the ability to apply knowledge to new situations, and creative mathematical problem solving (Huy, 2014; Matos et al., 2017). Student engagement has also been pursued through a non-classroom mentoring procedure that has enhanced student motivation and learning (Simões \& Alarcão, 2014).

Research shows that high-quality learning in students requires active guidance from teachers (Schwonke et al., 2011). Guidance may take the form of directive instructional talk, leading questioning and giving feedback, guiding questions tied to activities and tasks, and computer-aided programs (Chadli et al., 2018; Fuchs et al., 2013; Kim et al., 2018; Sun et al., 2014; van der Kleij et al., 2015; Wakefield et al., 2018). What matters here is that the teacher's attention focuses not only on the correctness or incorrectness of the student's response, but also on the student's personal thought process (van der Kleij et al., 2015). However, during the guiding and the giving of feedback, it is essential that students do not miss the opportunity to develop their own creative thinking and knowledge construction (Gresalfi et al., 2009). The assessment of teaching and learning also appears to be an influential factor in guiding the learning process. According to research, continuous assessment and appropriate guidance support student learning to a significant extent (Azigve et al., 2016; Csapó, 2007; Fuchs et al., 2008a, 2008b). Here, the key point is that the assessment is directed at the learning process and the student's learning potential, rather than merely at final outputs or the ability to do a particular mathematical task instantaneously. Studies have also shown that student participation in teaching assessment and learning the skill of self-assessment improve motivation and learning outcomes (Howard \& Crotty, 2017; Hughes et al., 2019).

There has been quite a lot of research into student participation and communication (O'Connor et al., 2017; Pampaka et al., 2012; Vista, 2016; Wood \& Kalinec, 2012). Studies have shown that the quality of mathematical talk plays a greater role in learning 
outcomes than the amount (O'Connor et al., 2017; Wood \& Kalinec, 2012). The guiding actions of the teacher are highly influential in focusing students' communication on what is relevant to the learning content. The aim is to draw their attention to the semantics of mathematical concepts and their own mathematical thinking, thereby leading to even better learning outcomes (van der Kleij et al., 2015; Vista, 2013; Wood \& Kalinec, 2012).

Participation in joint activities is strongly influenced by the emotional climate of the learning environment and the attitude of teachers towards their students. More specifically, studies highlight the teacher's readiness to consider students as individuals, which is also reflected in various teaching approaches (Bernacki \& Walkington, 2018; Hofmann \& Ruthven, 2018). As a result, students enjoy the class more, participate in joint work and act in a self-directed manner (Daschmann et al., 2011; Venkat \& Brown, 2009).

The role of the teacher as a facilitator of the student's learning process and a creator of the emotional climate in the learning environment is significant. Research results indicate that a teacher who treats students positively and warmly plays a leading role in creating a favourable emotional climate for meaningful learning (Daschmann et al., 2011; Jorgensen \& Niesche, 2008; Kiuru et al., 2015). Moreover, teaching methods (e.g., techniques, tools) influence the climate of the learning environment, which is further reflected through the student's motivation and commitment to learning outcomes (Azigve et al., 2016; Jorgensen \& Niesche, 2008; Venkat \& Brown, 2009).

Above we describe studies that were specifically targeted at teacher-student interaction during the teaching-learning process and the guidance of students in their learning. These studies highlight the importance of student participation, interaction and the quality of communication for meaningful learning. Perhaps the most significant factor here is the role of the teacher in guiding students in their studying. Attention is focused particularly on supporting them in developing their mathematical thinking, understanding and motivation, and engaging in the teaching-learning process.

\section{DISCUSSION}

The studies comprising our data revealed a number of approaches to teaching mathematics that were beneficial for meaningful learning. We also looked at the research data from a perspective that emphasized teacher-student interaction, which yielded more information in terms of forming the overall picture. In addition, we assessed the links between the various factors that were present in the studies as well as adherence to teaching solutions on the basis of learning outcomes (referring here to the development of the student's mathematical knowledge and skills).

In the previous section, we discussed the results of the research, the differing foci on approaches and educational interactions. In the following, through the merging of these elements, we aim to take the synthesis one step further. Our analysis revealed that mathematics teaching requires from the teacher, alongside the use of various approaches, high-quality activity to produce an optimal result. We have thus crystallized the seven conclusions about teaching aimed at meaningful learning. After presenting our conclusions we evaluate the implementation and limitations of our research, as well as the significance of our most substantial results.

1. Teacher guidance appears to be a prerequisite for quality mathematics learning. According to the studies, understanding mathematics seems to require the active guidance of students in their learning, regardless of the approach involved. Forms of guidance that support such work include orienting students towards new subjects, leading questioning, building guidance elements into learning tasks (e.g., auxiliary questions), and the use of relevant computer programs. It is worth pointing out, however, that guidance should not hinder the student's own creative thinking and active role as a builder of knowledge.

2. Recommended tutoring activities also include engaging students in the teaching-learning process, continuously assessing progress and giving encouraging feedback. A particularly crucial task is to initiate the teaching-learning process, which involves the fostering of internal motivation and a learning-goal orientation. Continuous assessment of their learning process also yields information on where to direct guidance and elaborated feedback that will give students the explanations they need. We suggest that their inclusion in the assessment and planning of teaching would be a considerable help in the development of teaching, although there are very few studies on the subject.

3. It is the teacher's task to choose a relevant context that promotes student interest in mathematics. To ensure meaningful learning, it is necessary to draw the attention of students to the conceptual links between mathematics content and the real world. It is therefore important to choose (or create) a context that is interesting and familiar from their everyday lives. Such contexts often include suitable problem-solving tasks that serve to trigger the teaching-learning process. The problem-solving process tends to incorporate various challenges, such as frustration in the face of a demanding problem. Studies show that good learning outcomes are nevertheless achievable, but this requires these affective problem-solving challenges to be addressed and treated as part of mathematics.

4. Supporting the understanding of mathematics requires well-chosen illustrative tools, and guidance in their use. Concrete physical instruments have long been used in mathematics teaching to illustrate a mathematical idea and facilitate its understanding. With the continued development of information technology, studies have increasingly focused on computer applications and their use in mathematics teaching, particularly in the form of learning games. Although they have helped to make students feel comfortable and motivated, and to engage in communal activities, neither these new IT nor traditional concrete instruments have always had the desired effect on learning outcomes. Nevertheless, wellchosen instruments and action-connected control may play a positive role in fostering an association between abstract mathematics and its external representations, thereby improving learning outcomes. 
5. The teacher is also responsible for monitoring the quality of communication among students and directing it towards the essential. Small group and collaborative working methods enable teachers to focus on guiding student communication. The conversations may not always be directed appropriately in terms of learning content, but in the light of our data, controlling how students communicate, focusing on quality (not quantity) and on the verbalization of mathematics improves learning outcomes. Only a few studies were included in our data, even though the verbalization of mathematics has emerged as a topic in recent years. It is clearly a structural part of the process by which students understand and internalize mathematics, and therefore a key factor in meaningful learning.

6. Meaningful learning in mathematics requires an affectively favourable learning environment. The formation of mathematical meanings requires the commitment of students to working in the long term. This, in turn, requires motivation and a favourable learning environment. Although various teaching approaches build on this, it is not enough. A major contributor to the teaching-learning process is the atmosphere in the learning environment and the social relations among its members. Research findings indicate that a welcoming, supportive and warm-minded teacher is a key factor in building an atmosphere that is favourable to meaningful learning. This is significant because their classroom experiences may have a far-reaching impact on how students feel about studying mathematics in the future.

7. Learning environments in which students are viewed as individuals as well as teaching built on their personal values foster learning in mathematics. For meaningful learning to take place the new mathematical content to be learned must be connected to the personal conceptual frame of reference and values adopted by the student. Thus, learning environments in which students are viewed as individuals improves learning outcomes. In particular, teaching that is built on the interests of students seems to have a positive impact on their motivation and learning. It could be concluded from the studies that deeper consideration of the student's personal thinking and world values will assume more importance in the future. Meaningful learning is a personal process, which can be supported by teacher guidance and a favourable learning environment.

Several factors contributed to the formation of our research findings, including our search of research data, the quality of the research articles included in the data, the way we analysed them, and the impact of the researcher's interpretation. We chose school education in mathematics as our target area, and we focused on meaningful learning. It was clear that our EBSCO search using keywords such as 'math*', 'teach"' and 'learning outcomes' would also produce research articles that did not match our focus (it yielded a total of 445 references). We excluded studies on early childhood education, special education, vocational education, and universities and other upper-age institutions from our final data set (69 studies). We decided to include studies that examined a set of subjects, but we limited the analysis to the results for maths. We also included studies in which the age range extended beyond the limits of our study, but we limited the analysis to the context of school mathematics.

We wanted to ensure that the search would identify as fully as possible studies in which the substance was relevant to our focus. As a result, we selected the final research articles based on our own judgement. The keyword 'learning outcomes' had a dual effect. It produced studies in which the mode of instruction under review was also linked to learning outcomes. At the same time, however, it produced quite a few studies on certain topics. The search would probably have identified more studies that highlighted teaching based on collaborative learning if we had extended it to cover the 1990s to the 2000s, for example. Currently, in turn, various IT teaching solutions, specifically learning games, are more popular with researchers. Consequently, our results are only relevant according to the search and the data it yielded. Lengthening the time slot and accessing different databases (e.g., Eric) would increase the research coverage in the future.

Although our data subjects tended to be students of a certain age or from certain grade levels, we did not distinguish them in our conclusions. One purpose of working with illustrative instruments is to proceed to an abstract examination of a symbolic level of mathematics, and this may happen more quickly with age. We took these age differences into account in the analyses, and they are also included in Tables 1-6 that list the studies covered in our article. Nevertheless, the research results, conclusions and recommendations we present herein should be applied to practice prudently.

We should also point out a number of limitations in our examination of the findings:

1. the precise limitation of empirical studies in the data and the specific perspective on our subject;

2. the conceptual fragmentation (with respect to other studies, such as expressing the same thing in different terms), which presents challenges in terms of integrating different perspectives; and

3. the fact that the results are not always explicitly or clearly described.

We have minimized the problem of subjectivity related to the researcher's interpretation by, among other things, presenting the studies and the results in tabular form (Tables 1-6), whereby argumentation relating to interpretations and conclusions are also visible to the reader. The studies included in the data (e.g., meta-analyses), on the other hand, mention some mutually contradictory individual studies, but this is noted in the results section and in the conclusions of the articles concerned. An example is Carbonneau et al.'s (2013) meta-analysis reporting that contrasting findings about the effects of concrete instruments on learning led to refinements in teaching.

The recommendations of the National Council of Teachers of Mathematics have led to a large amount of well-targeted empirical research. Efforts have also been made to bring together information deriving from the most specific research in the form of various synthesis studies, meta-analyses and systematic literature reviews. We found fewer synthesis studies, and most of them targeted learning disabilities (e.g., Liu et al., 2021; McKenna et al., 2015; Ok et al., 2020) or some other narrow area compared with our own research (e.g., Abdulrahim \& Orosco, 2020; Eames et al., 2021). For example, Abdulrahim and Orosco (2020) targeted the teaching of mathematics to linguistically diverse learners, whereas Eames et al. (2021) focused on learning about function as a concept. On the other hand, the previously mentioned studies of Tumkaya and Ulum (2016) and Nilsen and Gustafsson (2016) 
reflected more comprehensively the focus of our own research: Tumkaya and Ulum (2016) targeted their meta-analysis on approaches to teaching mathematics (such as the realistic approach, computer-aided learning and collaborative methods), whereas Nilsen and Gustafsson (2016) concentrated on teaching quality and practices (such as student activation, creating a climate that supports studying, and classroom management). In our own research we aimed at $a$ holistic synthesis of these various approaches and components of mathematics teaching when the focus is on meaningful learning in the context of school education. We did not find a similar study in our searches aimed at producing a holistic synthesis.

Regardless of the approaches, tools, and other teaching solutions in different contexts described in the individual studies, our research sheds light on the structures that connect them. "Components" of teaching such as approaches that suit the purpose, active guidance from the teacher during the learning process and an affectively favourable learning environment are required to achieve meaningful learning. Studies also show that different teaching approaches complement each other in effect (e.g., collaborative and computer-based solutions are often used in different contexts). Teaching that treats students as individuals and considers their personal qualities, promotes motivation and commitment to the teaching-learning process and to meaningful learning in mathematics. The optimal effect on learning outcomes would seem to arise when these different components complement each other and intertwine into an interactive entity.

Author contributions: All authors have sufficiently contributed to the study, and agreed with the results and conclusions.

Funding: No funding source is reported for this study.

Declaration of interest: No conflict of interest is declared by authors.

\section{REFERENCES}

Abdulrahim, N. A., \& Orosco, M. J. (2020). Culturally responsive mathematics teaching: A research synthesis. Urban Review, 52(1), 1-15. https://doi.org/10.1007/s11256-019-00509-2

Al-Washmi, R., Blanchfield, P., \& Hopkins, G. (2015). The efficacy of digital games to teach mathematics. In Proceedings of the 8th Annual International Conference on Computer Games, Multimedia \& Allied Technology 2015, 148-154. https://doi.org/10.5176/ 2251-1679_CGAT15.40

Amador, J. M. (2016). Teachers' considerations of students' thinking during mathematics lesson design. School Science \& Mathematics, 116(5), 239-252. https://doi.org/10.1111/ssm.12175

Azigwe, J. B., Kyriakides, L., Panayiotou, A., \& Creemers, B. P. M. (2016). The impact of effective teaching characteristics in promoting student achievement in Ghana. International Journal of Educational Development, 51, 51-61. https://doi.org/ 10.1016/j.ijedudev.2016.07.004

Benavides-Varela, S., Zandonella Callegher, C., Fagiolini, B., Leo, I., Altoè, G., \& Lucangeli, D. (2021). Effectiveness of digital-based interventions for children with mathematical learning difficulties: A meta-analysis. Computers \& Education, 157, 103953. https://doi.org/10.1016/j.compedu.2020.103953

Bernacki, M. L., \& Walkington, C. (2018). The role of situational interest in personalized learning. Journal of Educational Psychology, 110(6), 864-881. https://doi.org/10.1037/edu0000250

Berthold, K., \& Renkl, A. (2009). Instructional aids to support a conceptual understanding of multiple representations. Journal of Educational Psychology, 101(1), 70-87. https://doi.org/10.1037/a0013247

Brey, A., \& Tagney, B. (2018). Technology usage in mathematics education research-A systematic review of recent trends. Computers \& Education, 114, 255-273. https://doi.org/10.1016/j.compedu.2017.07.004

Brezovszky, B., McMullen, J., Veermans, K., Hannula-Sormunen, M. M., Rodríguez-Aflecht, G., Pongsakdi, N., Laakkonen, E., \& Lehtinen, E. (2019). Effects of a mathematics game-based learning environment on primary school students' adaptive number knowledge. Computers \& Education, 128, 63-74. https://doi.org/10.1016/j.compedu.2018.09.011

Byun, J., \& Joung, E. (2018). Digital game-based learning for K-12 mathematics education: A meta-analysis. School Science \& Mathematics, 118(3/4), 113-126. https://doi.org/10.1111/ssm.12271

Cai, J., Wang, N., Moyer, J. C., Wang, C., \& Nie, B. (2011). Longitudinal investigation of the curricular effect: An analysis of student learning outcomes from the LieCal Project in the United States. International Journal of Educational Research, 50(2), 117-136. https://doi.org/10.1016/j.ijer.2011.06.006

Cai, S., Liu, E., Yang, Y., \& Liang, J.-C. (2019). Tablet-based AR technology: Impacts on students' conceptions and approaches to learning mathematics according to their self-efficacy. British Journal of Educational Technology, 50(1), 248-263. https://doi.org/ $10.1111 /$ bjet.12718

Capar, G., \& Tarim, K. (2015). Efficacy of the cooperative learning method on mathematics achievement and attitude: A metaanalysis research. Educational Sciences: Theory \& Practice, 15(2), 553-559. https://doi.org/10.12738/estp.2015.2.2098

Carbonneau, K. J., Marley, S. C., \& Selig, J. P. (2013). A meta-analysis of the efficacy of teaching mathematics with concrete manipulatives. Journal of Educational Psychology, 105(2), 380-400. https://doi.org/10.1037/a0031084

Chadli, A., Tranvouez, E., Dahmani, Y., Bendella, F., \& Belmabrouk, K. (2018). An empirical investigation into student's mathematical word-based problem-solving process: A computerized approach. Journal of Computer Assisted Learning, 34(6), 928-938. https://doi.org/10.1111/jcal.12301 
Chazan, D., Herbst, P., \& Clark, L. (2016). Research on the teaching of mathematics: A call to theorize the role of society and schooling in mathematics instruction. In D. Gitomer, \& C. Bell (Eds.), Handbook of research on teaching (pp. 1039-1097). American Educational Research Association. https://doi.org/10.3102/978-0-935302-48-6_17

Christie, B., Beames, S., \& Higgins, P. (2016). Context, culture and critical thinking: Scottish secondary school teachers' and pupils' experiences of outdoor learning. British Educational Research Journal, 42(3), 417-437. https://doi.org/10.1002/berj.3213

Csapó, B. (2007). Research into learning to learn through the assessment of quality and organization of learning outcomes. Curriculum Journal, 18(2), 195-210. https://doi.org/10.1080/09585170701446044

Daschmann, E. C., Goetz, T., \& Stupnisky, R. H. (2011). Testing the predictors of boredom at school: Development and validation of the precursors to boredom scales. British Journal of Educational Psychology, 81(3), 421-440. https://doi.org/10.1348/ $000709910 \times 526038$

Davis, J. D. (2014). Reasoning-and-proving within Ireland's reform-oriented national syllabi. Mathematics Enthusiast, 11(3), 665705. https://doi.org/10.54870/1551-3440.1321

Dennis, M. S., Sharp, E., Chovanes, J., Thomas, A., Burns, R. M., Custer, B., \& Park, J. (2016). A meta-analysis of empirical research on teaching students with mathematics learning difficulties. Learning Disabilities Research \& Practice, 31(3), $156-168$. https://doi.org/10.1111/ldrp.12107

Di Leo, I., Muis, K. R., Singh, C. A., \& Psaradellis, C. (2019). Curiosity... confusion? Frustration! The role and sequencing of emotions during mathematics problem solving. Contemporary Educational Psychology, 58, 121-137. https://doi.org/10.1016/ j.cedpsych.2019.03.001

Duijzer, C., Van den Heuvel-Panhuizen, M., Veldhuis, M., Doorman, M., \& Leseman, P. (2019) Embodied learning environments for graphing motion: A systematic literature review. Educational Psychology Review, 31(3), 597-629. https://doi.org/10.1007/ s10648-019-09471-7

Eames, C. L., Graf, E. A., van Rijn, P. W., Budzban, G., \& Voepel, T. (2021). The finite-to-finite strand of a learning progression for the concept of function: A research synthesis and cognitive analysis. Journal of Mathematical Behavior, 62, 100864. https://doi.org/10.1016/j.jmathb.2021.100864

Ferrucci, B. J., McDougall, J., \& Carter, J. (2009/2010). Getting a BEAD on it. Mathematics Teaching in the Middle School, 15(5), 268273. https://doi.org/10.5951/MTMS.15.5.0268

Finfgeld, D. L. (2003). Metasynthesis: The state of the art-so far. Qualitative Health Research, 13(7), 893-904. https://doi.org/ $10.1177 / 1049732303253462$

Fuchs, L. S., Compton, D. L., Fuchs, D., Hamlett, C. L., DeSelms, J., Seethaler, P. M., Wilson, J., Craddock, C. F., Bryant, J. D., Luther, K., Geary, D. C., Schatschneider, C., \& Changas, P. (2013). Effects of first-grade number knowledge tutoring with contrasting forms of practice. Journal of Educational Psychology, 105(1), 58-77. https://doi.org/10.1037/a0030127

Fuchs, L. S., Compton, D. L., Fuchs, D., Hollenbeck, K. N., Craddock, C. F., \& Hamlett, C. L. (2008a). Dynamic assessment of algebraic learning in predicting third graders' development of mathematical problem solving. Journal of Educational Psychology, 100(4), 829-850. https://doi.org/10.1037/a0012657

Fuchs, L. S., Fuchs, D., Powell, S. R., Seethaler, P. M., Cirino, P. T., \& Fletcher, J. M. (2008b). Intensive intervention for students with mathematics disabilities: seven principles of effective practice. Learning Disability Quarterly, 31(2), 79-92. https://doi.org/ $10.2307 / 20528819$

Ge, L. (2012). Sequences of multiple representations in mathematics education. Journal of Applied Global Research, 5(14), 10-18.

Gresalfi, M., Martin, T., Hand, V., \& Greeno, J. (2009). Constructing competence: an analysis of student participation in the activity systems of mathematics classrooms. Educational Studies in Mathematics, 70(1), 49-70. https://doi.org/10.1007/s10649-0089141-5

Guo, J.-P., Yang, L.-Y., \& Ding, Y. (2014). Effects of example variability and prior knowledge in how students learn to solve equations. European Journal of Psychology of Education-EJPE (Springer Science \& Business Media B.V.), 29(1), $21-42$. https://doi.org/10.1007/s10212-013-0185-2

Hainey, T., Connolly, T. M., Boyle, E. A., Wilson, A., \& Razak A. (2016). A systematic literature review of games-based learning empirical evidence in primary education. Computers \& Education, 102, 202-223. https://doi.org/10.1016/ j.compedu.2016.09.001

Hiebert, J., \& Wearne, D. (1992). Links between teaching and learning place value with understanding in first grade. Journal for Research in Mathematics Education, 23(2), 98-122. https://doi.org/10.2307/749496

Hofmann, R., \& Ruthven, K. (2018). Operational, interpersonal, discussional and ideational dimensions of classroom norms for dialogic practice in school mathematics. British Educational Research Journal, 44(3), 496-514. https://doi.org/ 10.1002/berj.3444

Howard, S., \& Crotty, Y. (2017). The potential of an interactive game-based software to motivate high-achieving maths students at primary school level. Electronic Journal of Mathematics \& Technology, 11(2), 112-127.

Hughes, E. M., Lee, J-Y., Cook, M. J., \& Riccomini, P. J. (2019). Exploratory study of a self-regulation mathematical writing strategy: Proof-of-concept. Learning Disabilities-A Contemporary Journal, 17(2), 185-203.

Huy, P. P. (2014). An integrated framework involving enactive learning experiences, mastery goals, and academic engagementdisengagement. Europe's Journal of Psychology, 10(1), 41-66. https://doi.org/10.5964/ejop.v10i1.680 
Jorgensen, R., \& Niesche, R. (2008). Equity, mathematics and classroom practice: Developing rich mathematical experiences for disadvantaged students. Australian Primary Mathematics Classroom, 13(4), 21-27.

Kainose Mhlolo, M., \& Schafer, M. (2013). Consistencies far beyond chance: An analysis of learner preconceptions of reflective symmetry. South African Journal of Education, 33(2), 1-17. https://doi.org/10.15700/saje.v33n2a686

Kapur, M. (2014). Productive failure in learning math. Cognitive Science, 38(5), 1008-1022. https://doi.org/10.1111/cogs.12107

Ke, F. (2008). Computer games application within alternative classroom goal structures: Cognitive, metacognitive, and affective evaluation. Educational Technology Research \& Development, 56(5/6), 539-556. https://doi.org/10.1007/s11423-008-9086-5

Kim, N. J., Belland, B. R., \& Walker, A. E. (2018). Effectiveness of computer-based scaffolding in the context of problem-based learning for Stem education: Bayesian meta-analysis. Educational Psychology Review, 30(2), 397-429. https://doi.org/ 10.1007/s10648-017-9419-1

Kiuru, N., Aunola, K., Lerkkanen, M.-K., Pakarinen, E., Poskiparta, E., Ahonen, T., Poikkeus, A.-M., \& Nurmi, J.-E. (2015). Positive teacher and peer relations combine to predict primary school students' academic skill development. Developmental Psychology, 51(4), 434-446. https://doi.org/10.1037/a0038911

Kong, S. C. (2008). The development of a cognitive tool for teaching and learning fractions in the mathematics classroom: A designbased study. Computers \& Education, 51(2), 886-899. https://doi.org/10.1016/j.compedu.2007.09.007

Kul, U., \& Celik, C. (2020). A meta-analysis of the impact of problem posing strategies on students' learning of mathematics. Romanian Journal for Multidimensional Education, 12(3), 341-368. https://doi.org/10.18662/rrem/12.3/325

Leary, H., \& Walker, A. (2018). Meta-analysis and meta-synthesis methodologies: Rigorously piecing together research. TechTrends, 62(5), 525-534. https://doi.org/10.1007/s11528-018-0312-7

Lein, A. E., Jitenda, A. K., \& Harwell, M. R. (2020). Effectiveness of mathematical word problem solving interventions for students with learning disabilities and/or mathematics difficulties: A meta-analysis. Journal of Educational Psychology, 112(7), 13881408. https://doi.org/10.1037/edu0000453

Liu, M., Bryant, D. P., Kiru, E., \& Nozari, M. (2021). Geometry interventions for students with learning disabilities: A research synthesis. Learning Disabilty Quarterly, 44(1), 23-34. https://doi.org/10.1177/0731948719892021

Marshall, J. H., Ung, C., Nessay, P., Ung, N. H., Savoeun, V., Tinon, S., \& Veasna, M. (2009). Student achievement and education policy in a period of rapid expansion. International Review of Education, 55(4), 393-413. https://doi.org/10.1007/s11159-0099133-4

Matos, L., Lens, W., Vansteenkiste, M., \& Mouratidis, A. (2017). Optimal motivation in Peruvian high schools: Should learners pursue and teachers promote mastery goals, performance-approach goals or both? Learning \& Individual Differences, 55, 87-96. https://doi.org/10.1016/j.lindif.2017.02.003

Mavridis, A., Katmada, A., \& Tsiatsos, T. (2017). Impact of online flexible games on students' attitude towards mathematics. Educational Technology Research \& Development, 65(6), 1451-1470. https://doi.org/10.1007/s11423-017-9522-5

McKenna, J. W., Shin, M., \& Ciullo, S. (2015). Evaluating reading and mathematics instruction for students with learning disabilities: A synthesis of observation research. Learning Disabilty Quarterly, 38(4), 195-207. https://doi.org/10.1177/0731948714564576

Miller, S. C., \& Lindt, S. F. (2018). Engaging elementary students through movement integration in mathematics and reading-An exploratory study to understand teacher's perceptions. Curriculum \& Teaching Dialogue, 20(1-2), 31-43.

Modiba, M. (2011). Even the 'best' teachers may need adequate subject knowledge: An illustrative mathematics case study. Research in Education, 85(1), 1-16. https://doi.org/10.7227/RIE.85.1

Muis, K. R., Psaradellis, C., Chevrier, M., Di Leo, I., \& Lajoie, S. P. (2016). Learning by preparing to teach: Fostering self-regulatory processes and achievement during complex mathematics problem solving. Journal of Educational Psychology, 108(4), 474-492. https://doi.org/10.1037/edu0000071

National Council of Teachers of Mathematics. (2014). Principles to actions: Ensuring mathematical success for all. Author.

$\mathrm{Ni}$, Y., \& Cai, J. (2011). Searching for evidence of curricular effect on the teaching and learning of mathematics: Lessons learned from the two projects. International Journal of Educational Research, 50(2), 137-143. https://doi.org/10.1016/j.ijer.2011.06.007

Ni, Y., Li, Q., Li, X., \& Zhang, Z.-H. (2011). Influence of curriculum reform: An analysis of student mathematics achievement in Mainland China. International Journal of Educational Research, 50(2), 100-116. https://doi.org/10.1016/j.ijer.2011.06.005

Ni, Y., Zhou, D.-H. R., Cai, J., Li, X., Li, Q., \& Sun, I. X. (2018). Improving cognitive and affective learning outcomes of students through mathematics instructional tasks of high cognitive demand. Journal of Educational Research, 111(6), 704-719. https://doi.org/10.1080/00220671.2017.1402748

Nilsen, T., \& Gustafsson, J. E. (2016). Teacher quality, instructional quality and student outcomes. Relationships across countries, cohorts and time. Springer International Publishing. https://doi.org/10.1007/978-3-319-41252-8

Nizami, A. W., \& Mahmudi, A. (2018). Problem-solving-based learning to improve students' learning interest. AIP Conference Proceedings, 2014(1), 1-6. https://doi.org/10.1063/1.5054450

Norqvist, M., Jonsson, B., Lithner, J., Qwillbard, T., \& Holm, L. (2019). Investigating algorithmic and creative reasoning strategies by eye tracking. Journal of Mathematical Behavior, 55, 1-14. https://doi.org/10.1016/j.jmathb.2019.03.008 
Núñez Castellar, E., Van Looy, J., Szmalec, A., \& de Marez, L. (2014). Improving arithmetic skills through gameplay: Assessment of the effectiveness of an educational game in terms of cognitive and affective learning outcomes. Information Sciences, 264, 1931. https://doi.org/10.1016/j.ins.2013.09.030

Nye, E., Melendez-Torres, J. G., \& Bonell, C. (2016). Origins, methods and advances in qualitative meta-synthesis. Review of Education, 4(1), 57-79. https://doi.org/10.1002/rev3.3065

O'Connor, C., Michaels, S., Chapin, S., \& Harbaugh, A. G. (2017). The silent and the vocal: Participation and learning in whole-class discussion. Learning \& Instruction, 48, 5-13. https://doi.org/10.1016/j.learninstruc.2016.11.003

Ok, M. W., Bryant, D. P., \& Bryant, B. R. (2020). Effects of computer-assisted instruction on the mathematics performance of students with learning disabilities: A synthesis of the research. Exceptionality, 28(1), 30-44. https://doi.org/10.1080/ 09362835.2019.1579723

Olteanu, C., \& Holmqvist, M. (2012). Differences in success in solving second-degree equations due to differences in classroom instruction. International Journal of Mathematical Education in Science \& Technology, 43(5), 575-587. https://doi.org/10.1080/ 0020739X.2011.622807

Pampaka, M., Williams, J., Hutcheson, G., Wake, G., Black, L., Davis, P., \& Hernandez-Martinez, P. (2012). The association between mathematics pedagogy and learners' dispositions for university study. British Educational Research Journal, 38(3), 473-496. https://doi.org/10.1080/01411926.2011.555518

Reed, H. C., Drijvers, P., \& Kirschner, P. A. (2010). Effects of attitudes and behaviours on learning mathematics with computer tools. Computers \& Education, 55(1), 1-15. https://doi.org/10.1016/j.compedu.2009.11.012

Reid, J., \& Carmichael, C. (2015). A taste of Asia with statistics and technology. Australian Primary Mathematics Classroom, 20(1), 10-15.

Richey, J. E., Andres-Bray, J. M. L., Mogessie, M., Scruggs, R., Andres, J. M. A. L., Star, J. R., Baker, R. S., \& McLaren, B. M. (2019). More confusion and frustration, better learning: The impact of erroneous examples. Computers \& Education, 139, 173-190. https://doi.org/10.1016/j.compedu.2019.05.012

Richland, L. E., Begolli, K. N., Simms, N., Frausel, R. R., \& Lyons, E. A. (2017). Supporting mathematical discussions: The roles of comparison and cognitive load. Educational Psychology Review, 29(1), 1-13. https://doi.org/10.1007/s10648-016-9382-2

Rittle-Johnson, B., Star, J. R., \& Durkin, K. (2012). Developing procedural flexibility: Are novices prepared to learn from comparing procedures? British Journal of Educational Psychology, 82(3), 436-455. https://doi.org/10.1111/j.2044-8279.2011.02037.x

Rodríguez-Aflecht, G., Jaakkola, T., Pongsakdi, N., Hannula-Sormunen, M., Brezovszky, B., \& Lehtinen, E. (2018). The development of situational interest during a digital mathematics game. Journal of Computer Assisted Learning, 34(3), $259-268$. https://doi.org/10.1111/jcal.12239

Schwonke, R., Renkl, A., Salden, R., \& Aleven, V. (2011). Effects of different ratios of worked solution steps and problem solving opportunities on cognitive load and learning outcomes. Computers in Human Behavior, 27(1), 58-62. https://doi.org/10.1016/ j.chb.2010.03.037

Simões, F., \& Alarcão, M. (2014). The moderating influence of perceived competence in learning on mentored students' school performance. Learning \& Individual Differences, 32, 212-218. https://doi.org/10.1016/j.lindif.2014.03.009

Singer, F. M. (2009). The dynamic infrastructure of mind-A hypothesis and some of its applications. New Ideas in Psychology, 27(1), 48-74. https://doi.org/10.1016/j.newideapsych.2008.04.007

Slavin, R. E., Lake, C., \& Groff, C. (2009). Effective programs in middle and high school mathematics: A best-evidence synthesis. Review of Educational Research, 79(2), 839-911. https://doi.org/10.3102/0034654308330968

Smith, J. M., \& Mancy, R. (2018). Exploring the relationship between metacognitive and collaborative talk during group mathematical problem-solving-What do we mean by collaborative metacognition? Research in Mathematics Education, 20(1), 14-36. https://doi.org/10.1080/14794802.2017.1410215

Souvignier, E., \& Kronenberger, J. (2007). Cooperative learning in third graders' jigsaw groups for mathematics and science with and without questioning training. British Journal of Educational Psychology, 77(4), 755-771. https://doi.org/10.1348/ 000709906X173297

Sun, C.-T., Ye, S.-H., \& Hsieh, H.-C. (2014). Effects of student characteristics and question design on Internet search results usage in a Taiwanese classroom. Computers \& Education, 77, 134-144. https://doi.org/10.1016/j.compedu.2014.04.020

Thunder, K., \& Berry, R. (2016). The promise of qualitative metasynthesis for mathematics education. Journal for Research in Mathematics Education, 47(4), 318-337. https://doi.org/10.5951/jresematheduc.47.4.0318

Tokac, U., Novak, E., \& Thompson, C. G. (2019). Effects of game-based learning on students' mathematics achievement: A metaanalysis. Journal of Computer Assisted Learning, 35(3), 407-420. https://doi.org/10.1111/jcal.12347

Tumkaya, S., \& Ulum, H. (2020). A systematical review of the approaches enhancing the mathematics achievement. Journal of Education Culture and Society, 11(2), 171-182. https://doi.org/10.15503/jecs2020.2.171.182

van der Kleij, F. M., Feskens, R. C. W., \& Eggen, T. J. H. M. (2015). Effects of feedback in a computer-based learning environment on students' learning outcomes. Review of Educational Research, 85(4), 475-511. https://doi.org/10.3102/0034654314564881

Venkat, H., \& Brown, M. (2009). Examining the implementation of the mathematics strand of the key stage 3 strategy: what are the bases of evaluation? British Educational Research Journal, 35(1), 5-24. https://doi.org/10.1080/01411920802041665 
Vetter, M., Orr, R., O'Dwyer, N., \& O'Connor, H. (2020). Effectiveness of active learning that combines physical activity and math in schoolchildren: A systematic review. Journal of School Health, 90(4), 306-318. https://doi.org/10.1111/josh.12878

Vista, A. (2013). The role of reading comprehension in maths achievement growth: Investigating the magnitude and mechanism of the mediating effect on maths achievement in Australian classrooms. International Journal of Educational Research, 62(6), 2135. https://doi.org/10.1016/j.ijer.2013.06.009

Vitale, J. M., Black, J. B., \& Swart, M. I. (2014). Applying grounded coordination challenges to concrete learning materials: A study of number line estimation. Journal of Educational Psychology, 106(2), 403-418. https://doi.org/10.1037/a0034098

Volk, M., Cotič, M., Zajc, M., \& Istenic Starcic, A. (2017). Tablet-based cross-curricular maths vs. traditional maths classroom practice for higher-order learning outcomes. Computers \& Education, 114, 1-23.https://doi.org/10.1016/j.compedu.2017.06.004

Wakefield, E., Novack, M. A., Congdon, E. L., Franconeri, S., \& Goldin-Meadow, S. (2018). Gesture helps learners learn, but not merely by guiding their visual attention. Developmental Science, 21(6), 1-12. https://doi.org/10.1111/desc.12664

Wolgemuth, J.R., Hicks, T., \& Agosto, V. (2017). Unpacking assumptions in research synthesis: A critical construct synthesis approach. Educational Researcher, 46(3), 131-139. https://doi.org/10.3102/0013189X17703946

Wood, M. B., \& Kalinec, C. A. (2012). Student talk and opportunities for mathematical learning in small group interactions. International Journal of Educational Research, 51-52, 109-127. https://doi.org/10.1016/j.ijer.2011.12.008

Xie, C., Cheung, A. C. K., Lau, W. W. F., \& Slavin, R. E. (2020). The effects of computer-assisted instruction on mathematics achievement in Mainland China: A meta-analysis. International Journal of Educational Research, 102, 101565. https://doi.org/10.1016/j.ijer.2020.101565

Ziegler, E., Edelsbrunner, P. A., \& Stern, E. (2018). The relative merits of explicit and implicit learning of contrasted algebra principles. Educational Psychology Review, 30(2), 531-558. https://doi.org/10.1007/s10648-017-9424-4 